\title{
Frequency of transovarial transmission of dengue virus in Aedes aegypti mosquitoes in endemic areas of dengue hemorrhagic fever in Ceper District, Klaten Regency, Central Java Province, Indonesia
}

\author{
Novita Eka Putri ${ }^{1}$, Sitti Rahmah Umniyati ${ }^{1 *}$, and Elsa Herdiana Murhandarwati ${ }^{1}$ \\ ${ }^{1}$ Department of Parasitology, Faculty of Medicine, Public Health and Nursing Universitas Gadjah Mada, Indonesia
}

\begin{abstract}
Klaten Regency is an area in Central Java Province with a high rate of endemic dengue hemorrhagic fever. This study aims to demonstrate a correlation between transovarial transmission and the incidence of dengue haemorrhagic fever in Ceper District, Klaten Regency. Aedes larvae and pupae were collected from January 2019 to March 2019 from various containers, using gamadotic and dipper tools, in Ngawonggo, Kajen, and Meger villages, which have high, medium, and low numbers of dengue cases, respectively. The larvae and pupae obtained were reared into adults. The presence of dengue virus in head squashes of 1-week-old female Ae. aegypti was identified based on an immunocytochemical assay using DSSE10 monoclonal antibody, made at Universitas Gadjah Mada as a primary antibody. The frequency of transovarial transmission of dengue virus (TIR) in Ae. aegypti in the three villages was $35.7 \%$. The highest frequency occurred in Ngawonggo Village, at $40 \%$, and the lowest in Meger Village, at 28\%, while the frequency in Kajen Village was $36.9 \%$. This study proves that there is a strong correlation $(r=0.99664)$ between transovarial transmission and the incidence of dengue hemorrhagic fever in Ceper District, Klaten Regency, Central Java. Keywords: Dengue hemorrhagic fever, Aedes aegypti, immunocytochemical assay, transovarial, Klaten
\end{abstract}

\section{Introduction}

Dengue haemorrhagic fever (DHF) is an important health problem in tropical and subtropical countries, including Indonesia. The prevalence of DHF is still high, especially in big cities. According to the Indonesian Ministry of Health (2018), there were 59047 dengue cases in 34 provinces in Indonesia. The incidence rate was 23 cases per 100000 populations, the case fatality rate was $0.75 \%$, and there were 444 cases died [1]. According to the Central Java Health Office (2016), Klaten Regency in Central Java Province is an area with high endemic DHF [2]. In 2015 there were 525 DHF cases with 26 deaths, and there was an increase to 703 DHF cases with 22 deaths in 2016. Of the 26 districts that make up Klaten Regency, Ceper District is one of the areas with the highest endemic dengue. Klaten Health Office increased the source reduction of mosquito breeding sites and formed Juru pemantau jentik (larval surveyor) in 2017, and this activity succeeded in reducing dengue cases to 101 cases with three deaths [3]. This condition may be related to the role of transovarial transmission of dengue virus (DENV) in the dengue vector during the epidemic of DHF. It is known that the transovarial transmission of DENV in Aedes spp. mosquitoes is an important mechanism in the maintenance of the virus in nature and may be implicated in outbreaks and epidemics of the disease [4]. However, there have been few studies involving transovarial transmission and viral vector monitoring as a surveillance tool and control strategy.

A better understanding of dengue outbreaks, especially in spatial patterns, will help in planning the allocation of resources for the prevention and control of dengue fever [5]. Successfully implementing the Klaten Health Service's program for reducing dengue cases requires monitoring activities to find out or to map the potential dengue locations. One of the monitoring activities is dengue vector surveillance. Dengue vector surveillance activities (tracking Aedes aegypti and Aedes albopictus) can then be used as a reference in making decisions or policies for vector control. Dengue vector surveillance in Indonesia is only based on the population density of the immature stage such as Angka Bebas Jentik, without confirmation by virology testing.

There are several methods for mosquito virus detection, including the direct fluorescent antibody (DFA) test on mosquito tissues, usually brain or salivary glands or head squashes, and reverse-transcription polymerase chain reaction (RT-PCR). However, the DFA method has the disadvantages of being labourintensive and requiring a fluorescent microscope and

\footnotetext{
* Corresponding author: sitti-rahmah@ugm.ac.id
} 
cryofreezer. Other methods involving enzyme conjugates such as peroxidase and phosphatase in conjunction with either polyclonal or monoclonal antibodies provide great improvements. A monoclonal antibody against DENV has been produced through three-time fusion by the dengue team of Gadjah Mada University (GMU). The result was $50 \mathrm{~mL}$ of antibody against DENV secreted by DSSC7 hybrid cells in the ascites of two Balb/c mice. The monoclonal antibody DSSC7 belongs to the immunoglobulin $\mathrm{G}$ ( $\mathrm{IgG}$ ) class, IgG1 subclass. The monoclonal antibody recognized the DENV complex specific epitope and had no crossreactivity against Chikungunya antigen, based on Western blotting analyses [6]. Immunocytochemical streptavidin-biotin peroxidase complex (ISBPC) assays using monoclonal antibody DSSC7 as a primary antibody have been standardized by Umniyati [7] to detect the dengue viral antigen in head squashes of Aedes aegypti mosquitoes. The dengue antigen was detected as a brownish color in the cytoplasm of infected cells throughout most fields of the brain tissue of infected Ae. aegypti mosquitoes. A negative result was shown on head squashes of uninfected Ae. aegypti from an area without endemic DHF and with head squashes of Anopheles mosquitoes as a blue colour throughout most fields having brain tissue, with no brownish colour other than the chitinous mosquito tissues and nonspecific background, which was thus distinct from the specific positive result. The agreement (kappa) value between two observers for the immunocychemical assay is 0.92 , with a sensitivity and specificity of $96 \%$ and 97 $\%$, respectively, for detecting dengue viral antigen on head squashes preparations at a magnification of $1000 \times$ under a light microscope [7].

Based on the preceding explanation, the objective of this study is to apply the immunocytochemical technique for virological surveillance through detection of transovarial infection in the endemic dengue area of DHF in Kecamatan Ceper, Klaten Regency, and to apply a geographical information system to describe the influence of high transovarial transmission on the incidence of dengue hemorrhagic fever in Ceper District, Klaten Regency, Central Java.

\section{Materials and Methods}

\subsection{Study Area}

A cross-sectional design was used in this study in Ceper District, Klaten Regency, from January 2019 to March 2019. From five dengue-endemic villages in Ceper District, three villages that had the highest, medium, and low number of cases were selected. The highest number of cases was in the Ngawonggo area (10 cases), the moderate number was in the Kajen area ( 8 cases), and the lowest number was in the Meger area (4 cases) [3]. Ngawonggo is a densely populated metal casting industrial area. Kajen is an area dominated by rice fields, and almost every house has a garden plot. Meger is an area in the vicinity of the main provincial road, allowing higher population mobility.

\subsection{Larval Surveys}

Larval surveys were carried out in houses where dengue cases lived and in surrounding houses. The numbers of houses surveyed were determined by the number of houses and the level of house index (HI) according to the World Health Organization (WHO) (Table 1.) [8]. At least 57 houses in Meger Village, 129 houses in Kajen Village, and 57 houses in Ngawonggo Village could be surveyed, based on the data in Table 1. Based on WHO guidelines, of 965 houses with an HI value of $>5 \%$ in Meger Village, 57 houses were surveyed. Of 853 houses with an HI value of $>2 \%$ in Kajen Village, 129 houses were surveyed, and of 1490 houses with an HI value of $>5 \%$ in Ngawonggo Village, 57 houses were surveyed. The houses surveyed were those within a 100-meter radius of the houses of dengue sufferers. Each house was surveyed to check the existence of larvae.When larvae were found, the geographical positioning system coordinates were noted. Larvae found in containers both inside and outside the house were collected using a dipper and a gamadotic tool [9]. The larvae obtained from the survey were then put into labeled plastic bags and taken to the FKKMK UGM Yogyakarta Parasitology Laboratory to be fostered until adulthood. Adult mosquitoes were fed with a $10 \%$ sugar solution every day [9].

Table 1. The minimal number of houses to be surveyed in the location of dengue cases based on the house index data (8).

\begin{tabular}{llll}
\hline Number of & \multicolumn{3}{l}{ House Index(HI) } \\
Houses & $>1 \%$ & $>2 \%$ & $>5 \%$ \\
\hline 100 & 95 & 78 & 45 \\
200 & 155 & 105 & 51 \\
300 & 189 & 117 & 54 \\
400 & 211 & 124 & 55 \\
500 & 225 & 129 & 56 \\
1000 & 258 & 138 & 57 \\
2000 & 277 & 143 & 58 \\
5000 & 290 & 147 & 59 \\
10000 & 294 & 148 & 59 \\
$>10000$ & 299 & 149 & 59 \\
\hline
\end{tabular}

Table 2. Distribution frequency of dengue virus in the villages of Meger, Kajen and Ngawonggo.

\begin{tabular}{llll}
\hline $\begin{array}{l}\text { Name of } \\
\text { Village }\end{array}$ & $\begin{array}{l}\text { Number of } \\
\text { houses } \\
\text { surveyed }\end{array}$ & $\begin{array}{l}\text { Houses of } \\
\text { positive } \\
\text { virus }\end{array}$ & $\begin{array}{l}\text { Number of } \\
\text { Dengue } \\
\text { Cases }\end{array}$ \\
\hline Ngawonggo & 57 & 9 & 10 \\
Kajen & 129 & 11 & 8 \\
Meger & 57 & 5 & 4 \\
\hline
\end{tabular}




\subsection{DENV Immunocytochemistry Examination}

As described by Umniyati [7], the immunocytochemistry streptavidin-biotin peroxidase complex (ISBPC) assay was performed with slight modification. First, 1-week-old mosquitoes were killed by putting them in the freezer. Head squashes of mosquitoes were prepared as follows: The mosquito head (caput) was separated from its cervix using a mosquito surgery needle on an objective glass. On another objective glass coated with poly-L-lysine, 10 caputs were pressed under a cover glass using the back of a mosquito surgical needle made of wood. The cover glass and crude tissue on the objective glass were removed and put into a bottle filled with $70 \%$ alcohol. The slide was dried at room temperature for about 30 min. Afterward, it was fixed with cold methanol $(-20$ ${ }^{\circ} \mathrm{C}$ ) in a freezer for $3 \mathrm{~min}$ to $5 \mathrm{~min}$, and then dried at room temperature and washed with phosphate-buffered saline (PBS). To eliminate the endogenous peroxidase activity, the slides were soaked in peroxidase blocking solution ( 1 part of $30 \%$ hydrogen peroxide +9 parts of absolute methanol) at room temperature for $10 \mathrm{~min}$. Each slide was blocked in $30 \mu \mathrm{L}$ of prediluted blocking solution for $10 \mathrm{~min}$ at room temperature $\left(25^{\circ} \mathrm{C}\right)$; then $100 \mu \mathrm{L}$ primary antibody (DSSC71:10) monoclonal antibody was added to each slide (adjusted until all parts were soaked), which was incubated on a damp tray at room temperature $\left(25^{\circ} \mathrm{C}\right)$ for $60 \mathrm{~min}$ or overnight in the refrigerator. The slides were then each washed with PBS $2 \times$ for $2 \mathrm{~min}$; $100 \mu \mathrm{L}$ biotinylated universal secondary antibody was added to each slide, and the slides were incubated at room temperature $\left(25^{\circ} \mathrm{C}\right)$ for $10 \mathrm{~min}$.

The slides were then each washed with PBS $2 \times$ for 2 min, and each slide was incubated with $30 \mu \mathrm{L}$ streptavidin peroxidase complex conjugate or tetravidin horseradish peroxidase (HRP) for $10 \mathrm{~min}$, and then each was washed with PBS $2 \times$ for 2 min. Betazoid DAB chromogen solution was prepared by mixing $100 \mu \mathrm{L}$ of DAB chromogen with a buffer substrate of $900 \mu \mathrm{L}$. Each slide then was incubated in $100 \mu \mathrm{L}$ of peroxidase substrate solution (DAB) for $5 \mathrm{~min}$, and then washed with tap water; then $100 \mu \mathrm{L}$ of Mayer haematoxylin (counterstain) was added, incubated for $1 \mathrm{~min}$, and then washed with tap water and rinsed with PBS $1 \times$ for $1 \mathrm{~min}$. The slides were then dehydrated in 100\% alcohol three times, and then cleared in xylene for $3 \mathrm{~min}$ in a staining jar. Drops of mounting media were added to each slide and covered with a cover glass. After being dried, the slide was ready to be evaluated under a light microscope with a magnification of $40 \times, 100 \times, 400 \times$, and $1000 \times$. When the slide shows a brown colour, this means that the preparation contains DENV antigen; when the preparation shows a blue or pale colour (as in the negative control), this means that the preparation does not contain DENV antigen. For the positive control, a 1or 2-day-old Ae. aegypti mosquito from the Department of Parasitology, FKKMK, UGM, was injected with the DENV as described by Putri et al. [10], whereas for the negative control, Culex sp. mosquitoes were used because they were not a vector of DENV.

\section{Results}

The results are based on the examination of DENV in head squashes of Ae. aegypti using monoclonal antibody DSSE10, made at UGM by the Dengue Team of UGM. According to Umniyati (2009), in previous studies the monoclonal antibody DSSE10 showed strong immunoreactivity to Dengue-1, Dengue-2, Dengue-3, and Dengue-4 viruses, and has shown no cross-reaction to Japanese encephalitis and Chikungunya antigens, based on inhibition ELISA [11]. The monoclonal antibody was produced again in the ascitic fluid of Blab/c mice in 2010. The monoclonal antibody DSSE10 belongs to the IgG class, IgG1 subclass [12]. The agreement (kappa) value between two observers for the immunocytochemical assay using the DSSE10 monoclonal antibody is 0.63 with a sensitivity and specificity of $100 \%$ and $91 \%$, respectively [13]. DENV examination using the immunocytochemical method in the Ae. aegypti head squashes preparation is presented in Figure 1.

Immunohistochemistry is a method used in tissues or cells for visualizing and localizing antigens that interact with specific antibodies, binding to antibodies labelled with, for example, peroxidase enzymes or alkaline phosphatase in light-microscopic preparations. This method uses secondary antibodies labelled with biotin that can recognize primary antibodies (monoclonal antibodies or polyclonal antibodies) and uses streptavidin conjugates labelled with the horseradish peroxidase enzyme and chromogen substrate mixture to detect antigens in cells or tissues with very high sensitivity. Therefore, antigens can be detected even at a low level. The main basis of the SBPC reaction is a very strong bond between streptavidin and biotin $(\mathrm{K}=$ $10-15 \mathrm{M})$. The primary antibody was incubated with the target antigen for $10 \mathrm{~min}$ and washed with phosphate buffer three times. This procedure was followed by addition of secondary antibodies labelled with biotin, which functions as a link between the primary antibody and the streptavidin-peroxidase conjugate. The streptavidin-peroxidase conjugate is then added to bind the biotin residue. Enzymes can be demonstrated by adding a mixture of chromogen substrate solution. The peroxidase enzyme will catalyse the substrate, hydrogen peroxide, and convert chromogens to brown deposits that indicate the presence of antigens there. Accordingly, a positive result is shown by the presence of brown in tissue slices, where the colour intensity depends on the amount of chromogen that reacts with the peroxidase enzyme. This reaction does not occur in antigen-negative cells. As a result, antigen-negative cells will absorb the haematoxylin colour of blue. The positive control and positive sample in Figure 1 show a brown colour indicating the presence of dengue antigens, while the negative control and the negative sample, showing blue, indicate the absence of dengue antigens [11]. 
250 ung

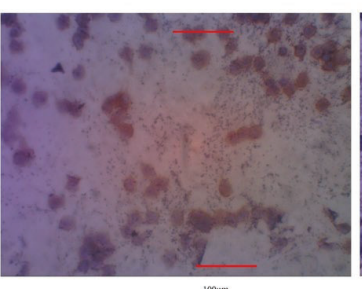

Gambar IC: ${ }^{100 \text { mun }}$

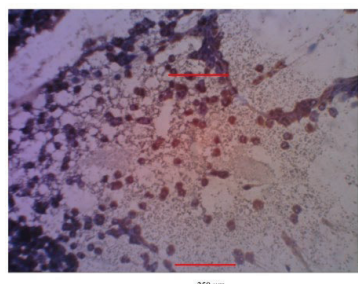

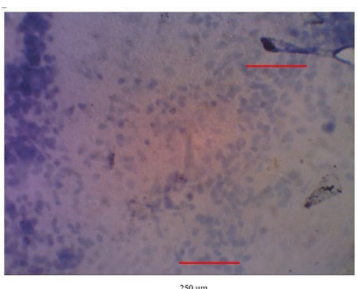

$\underset{\text { Gambor IB. }}{250 \mathrm{\mu m}}$

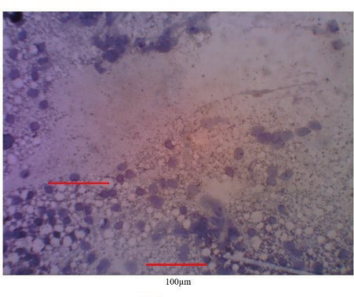

Gambar ID.
Fig 1. (A) Photomicrograph at 400x magnification of Head squashes of intrathoracically-infected Ae.aegypti with DENV3 at incubation period of seven days as positive control. (B) Photomicrograph of head squash of Culex sp as negative control shows blue coloration of brain cells (negative reaction). (C) One of positive samples of head squash of one week old female Ae. aegypti originated from dengue endemic area in Ceper District, Klaten Regency, Central Java Province, Indonesia at larval stage, then reared to adult without blood fed in the insectary of Department of Parasitology, Faculty of Medicine, Public Health and Nursing UGM. (D). One of negative samples of head squash of one week old female Ae. aegypti originated from dengue endemic area in Ceper District, Klaten Regency, Central Java Province, Indonesia at larval stage, then reared to adult without blood fed in the insectary of Department of Parasitology, Faculty of Medicine, Public Health and Nursing UGM.

Table 3. Pearson product moment correlation coefficient of transovarial transmission of DENV in Ae. aegypti to the dengue cases in three villages in Ceper District, Klaten Regency, Central Java.

\begin{tabular}{|l|l|l|l|}
\hline Name of & $\begin{array}{l}\text { Number } \\
\text { of }\end{array}$ & TIR & $\begin{array}{l}\text { Pearson product } \\
\text { moment }\end{array}$ \\
\hline Village & cases & $(\%)$ & Correlationt coefficient \\
\hline $\begin{array}{l}\text { Ngawongg } \\
\text { o }\end{array}$ & 10 & 40 & $\mathrm{r}=0.99664$ \\
\hline Kajen & 8 & $\begin{array}{l}36 . \\
9\end{array}$ & \\
\hline Meger & 4 & 28 & \\
\hline Total & 22 & $\begin{array}{l}35 . \\
7\end{array}$ & \\
\hline
\end{tabular}

The results from detection of DENV in the Meger, Kajen, and Ngawonggo villages, Ceper District, Klaten Regency, are presented in Table 2. Table 2. shows that transovarial transmission occurred in Ae. aegypti mosquitoes in dengue-endemic villages in Ceper District. There were 199 mosquitoes examined, and 71 were found to be positive for dengue $(35.7 \%)$. The results showed that Ngawonggo Village had the highest transovarial transmission of DENV (TIR) (40 \%), Kajen Village had the second highest TIR (36.9\%), and Meger Village had the lowest TIR $(28 \%)$. The results also showed a strong correlation between transovarial transmission and the incidence of DHF in Ceper District, Klaten Regency, Central Java (Table 3). A map of the cases and another of locations positive for mosquitoes in selected areas of the three examined villages in Ceper District, Klaten Regency, are presented in Figure 2.

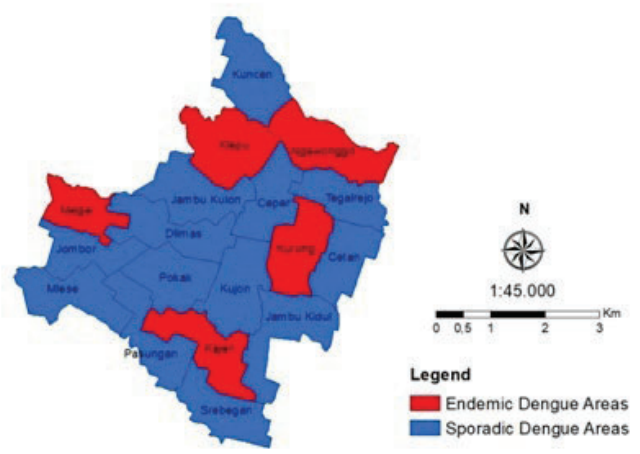

A

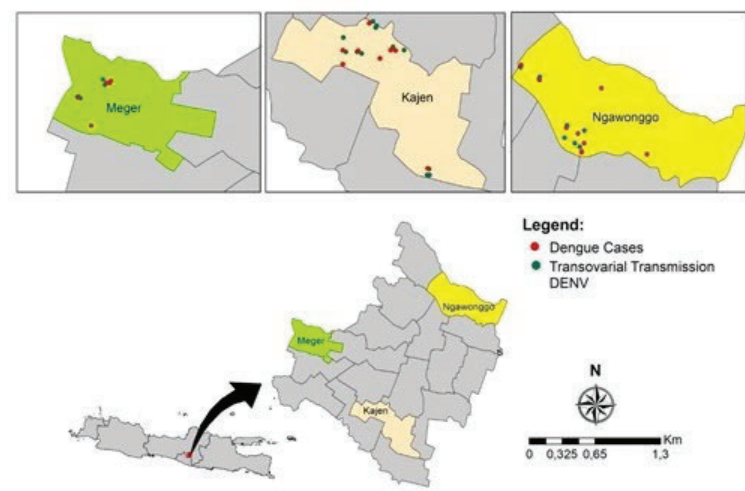

$\mathrm{B}$

Fig 2. Map of dengue cases and positive mosquitoes locations in selected area of three villages: Meger (green), Kajen (brown), Ngawonggo (yellow) in Ceper District, Klaten Regency, Central Java Province, Indonesia.

\section{Discussion}

Almost two-thirds of the participants had limited health literacy indexes when measuring general health literacy with the HLS-EU-Asia-Q (Fig. 1). It was consistent with previous studies in Indonesia (10-13). Small differences were found in the index scores of each health literacy domain, with disease prevention the lowest (Table 2). Therefore, health knowledge needs to be increased among the adult population in Yogyakarta City, with special emphasis on disease prevention programs.

The HLS-EU-Asia-Q is a comprehensive tool for the health literacy survey that has been validated in Asia [7]. It assesses four information-processing domains (finding, understanding, judging, and applying) and three health domains (health care, disease prevention, and health promotion), which cover a broader concept of health literacy in populations and communities [14]. It was suggested to use the same tool to assess health literacy in Asia to provide comparisons within or between countries in the future [7]. 
Some sociodemographic factors which are associated with lower health literacy (female, age $\geq 65$ yr, having long term illness, lower income and lower education) [15] were not statistically significant for predicting lower health literacy in this study $(p>0.05)$. Several similar studies have also failed to prove the influence of sex, age, education, and income on health literacy, although many theories support the influence of sociodemographic characteristics on health literacy (1620).

Still, the amount of drug information received by patients is significantly different for respondents with limited health literacy indices $(\mathrm{p} \leq 0.05)$. The authors suggest that patients with complete information about their medications will be better informed and thus more likely to make the right health decisions, and thus better health literacy scores.

When there is association between the amount of drug information received and health literacy index scores, it is possible to optimize the content of drug information to patients to improve health literacy. Though there are many factors to be taken into account in designing the appropriate interventions, education and provision of drug information can be one of the most effective interventions to improve health literacy.

The high percentage of respondents who have received a sufficient amount of drug information indicates that pharmacists have been providing sufficient information to patients. Patients could remember that they actually received quite complete information about their medications. Unfortunately, the completeness of the information conveyed does not necessarily equate with patient comprehension of the medication.

Jacobson et al have proposed an intervention-area model for the improvement of health literacy that can be done by pharmacists [1]. In cases where patients have limited levels of health literacy, pharmacists are not simply required to provide complete drug information, such as all items in the questionnaire, but to also emphasize face-to-face counseling. Pharmacists are actually encouraged to use literacy-sensitive techniques in providing drug information to patients. Literacysensitive techniques include the repetition of information by the patient, asking open questions, explanations using tools, demonstrations of drug use, using print materials, and the provision of treatment cards that help patients remember drug use rules. Surely this should be supported by facilities, whether in their pharmacies or pharmacy installations, as well as trained pharmacists to provide treatment information to patients with limited health literacy.

Since communication with pharmacists before patients receive medication is the last gate to ascertain whether they truly understand their condition and treatment plans, the role of pharmacist becomes extremely important in helping patients achieve optimal health outcomes and prevent medication errors. This can be accomplished if the pharmacists are able to tailor health information services to the patients' health literacy levels.

This study had limitations. The amount of drug information was used as a proxy to drug information services. That required not only sufficient quantity but also quality of communication. Therefore, the amount of drug information provided might not accurately describe the medication knowledge possessed by patients. Subsequently, there might be bias because of selfreporting questionnaires. Positive or negative answers might be affected by patients' feelings when answering the questionnaire.

Finally, the sample size was relatively small compared to national surveys, with a non-random sampling method that can affect the generalizability of the study. Thus, the results of this study should not be interpreted as results from national survey.

\section{Conclusion}

This study proves that there is a high frequency of transovarial transmission of DENV in $A e$. aegypti in areas endemic for dengue in Ceper District, Klaten Regency, Central Java, and there is a strong correlation between transovarial transmission and the incidence of DHF here $(r=0.99664)$.

The author would like to thank Klaten District Health Office and the head of Department of Parasitology of the Faculty of Medicine, Public Health and Nursing, GMU for the permission to carry out this research, and Research Directorate, GMU, for funding through the student final assignment recognition (Rekognisi Tugas Akhir) 2019 period. Thanks are also due to technicians for their valuable assistance in the laboratory. This study obtained approval from Medical And Health Research Ethics Committee Faculty of Medicine GMU (Reference number: KE/FK/1285/EC/2018).

\section{References}

1. Kemenkes RI:: Data dan Informasi Profil Kesehatan Indonesia 2016. Ditjen P2P, Kemenkes RI. 2016. [Internet]. Available from: https://www.kemkes.go.id/resources/download/pus datin/lain-

lain/Data $\% 20$ dan $\% 20$ Informasi $\% 20$ Kesehatan $\% 20$ Profil $\% 20$ Kesehatan\%20Indonesia\%202016\%20$\% 20 \% 20$ smaller $\% 20$ size $\% 20-\% 20$ web.pdf, cited in Feb 25, 2020

2. Dinkes Jateng.: Profil Kesehatan Provinsi Jawa Tengah Tahun 2016. Semarang: Dinas Kesehatan Provinsi Jawa Tengah. 2016. [Internet]. Available from:

http://dinkesjatengprov.go.id/v2018/dokumen/prof il2016/mobile/index.html $\# \mathrm{p}=315$ cited in Feb 25, 2020

3. Dinkes Klaten.: Profil Kesehatan Kabupaten Klaten Tahun 2015. Klaten : Dinas Kesehatan Kabupaten Klaten. 2016. [Internet]. Available from: https://docplayer.info/59069436-Profilkesehatan-kabupaten-klaten-tahun-2015.html, cited in Feb 25, 2020

4. Joshi, V., Mourya, D.T., Sharma, R.C.: Persistence of dengue- 3 virus through transovarial transmission passage in successive generations of Aedes aegypti mosquitoes. Am. J. Trop. Med. 
Hyg. 67, 158-161 (2002). https://doi.org/10.4269/ajtmh.2002.67.158

5. Li, Q., Cao, W., Ren, H., Ji, Z., Jiang, H.: Spatiotemporal responses of dengue fever transmission to the road network in an urban area. Acta Trop. 183, 8-13 (2018). https://doi.org/10.1016/j.actatropica.2018.03.026

6. Umniyati, S.R., Sutaryo, Wahyono, D., Artama, W.T., Mardihusodo, S.J., Soeyoko, Mulyaningsih, B., Utoro. T.: Application of monoclonal antibody DSSC7 for detecting dengue infection in Aedes aegypti based on immunocytochemical streptavidin biotin peroxidase complex assay (ISBPC). Dengue Bulletin 32, 83-91(2008).

7. Umniyati, S.R.: Standardization of Immunocytochemical method for the diagnosis of Dengue Viral Infection in Aedes aegypti Linn Mosquitoes (Diptera Culicidae). B I Ked. 41(1):110 (2009).

8. WHO.: Prevention and Control of Dengue and Dengue Haemorragic Fever Comprehensive guidelines. WHO Regional Publication, SEARO No. 29. World Health Organization, India (1999).

9. Umniyati, S.R., Sari, A.P., Kusumasari, R.A.: Pupal survey using Gamadotik device and identify dengue virus using gama monoclonal antibody. Bandung International Sciences meeting on Parasitology and Tropical Diseases. Challenges in parasitology in the era globalization: from basic to diagnostic and clinical application. May 1st-2nd, Bandung (2014).

10. Putri, D.F., Widya, A., Sugeng, M.J., Sitti, U.R.: The Potency of Polygamy Behavior in Aedes aegypti Mosquitoes by Venereal Transmission Dengue Virus. J. Kesehat. Masy. 13, 382-388 (2018). https://doi.org/10.15294/kemas.v13i3.11639

11. Umniyati, S.R.: Immunocytochemistry using monoclonalantibody DSSC7 for understanding the pathogenesis of Dengue virus infection and transovarial transmission and virologic surveilance of Dengue vector [dissertation]. Yogyakarta. Univ Gadjah Mada; Indonesian. (2009)

12. Umniyati, S.R., Sutaryo, Wahyono, D., Artamma, W.T.: Development of monoclonal antibody against dengue virus produced by dengue team of Gadjah Mada University for early detection of dengue virus infection on febrile patients. In Vitro Diagnostics Technology and Industry Development Summit, eChinaChem. June18th20th, 2011, Shanghai, China (2010).

13. Widiastuti, D., Yunianto, B., Umniyati, S.R., Wijayanti, N.: Sensitivity and specificity of immunocytochemical assay for detection of Dengue virus 3 infection in mosquito. Heal. Sci. J. Indones. 2, 87-91 (2011)

14. Umniyati, S.R.: Prelimenary investigation on the transovarial transmission of dengue virus in the population of Aedes aegypti in the well. Seminar Hari Nyamuk IV. August 21; Surabaya (2004)
15. Angel, A., Angel, B., Joshi, V.: Rare occurrence of natural transovarial transmission of dengue virus and elimination of infected foci as a possible intervention method. Acta Trop. 155, 20-24 (2016). https://doi.org/10.1016/j.actatropica.2015.11.018

16. Karyadi.: Status entomologi vektor nyamuk Aedes aegypti (Diptera: culicidae) dan analisis spasial kasus demam berdarah dengue (DBD) di Kecamatan Sanggata Utara, Kabupaten Kutai Timur. [Thesis] Universitas Gadjah Mada, Yogyakarta (2015).

17. Wanti.: Demam berdarah dengue di kota kupang: kondisi iklim status entomologis dan bukti adanya infeksi transovarial dengue pada nyamuk Aedes aegypti dan Aedes albopictus (diptera:culicidae). [Thesis] Universitas Gadjah Mada, Yogyakarta (2010).

18. Mardihusodo, S.J., Satoto, T.B.T., Mulyaningsih, B., Umniyati, S.R., Ernaningsih.: Bukti adanya penularan virus dengue secara transovarial pada nyamuk Aedes aegypti di Kota Yogyakarta. Simposium Nasional Aspek Biologi Molekuler, Patogenesis, Manajemen dan Pencegahan KLB. Pusat Studi Bioteknologi UGM. May 16; Yogyakarta. (2007).

19. Lee, H.L., Rohani, A.: Transovarial transmission of dengue virus in Aedes aegypti and Aedes albopictus in relation to dengue outbreak in an urban area in Malaysia. Dengue Bulletin 29, 106111 (2005)

20. Thongrungkiat, S., Maneekan, P., Wasinpiyamongkol, L., Prummongkol, S.: Prospective field study of transovarial denguevirus transmission by two different forms of Aedes aegypti in an urban area of Bangkok, Thailand. J. Vector Ecol. 36, 147-152 (2011). https://doi.org/10.1111/j.1948-7134.2011.00151.x 